\title{
Determinants of Savings among Smallholder Farmers in Sokoto South Local Government Area, Sokoto State, Nigeria
}

\author{
Tohib Oyeyode OBALOLA ${ }^{1 *}$, Rabiu Omeiza UUDU $^{2}$, Samuel Temitope DANILOLA $^{2}$
}

Received December 21, 2017; accepted May 13, 2018.

Delo je prispelo 21. decembra 2017, sprejeto 13. maja 2018.

\begin{abstract}
Low savings in the economy could lead to ineffective mobilization of funds for domestic investment. This could be part of the reason why Nigeria depends heavily on external borrowing for its developmental and investment projects. There is little or no documented evidence from available literatures of savings culture of farmers in the area. The dearth of such conclusive evidence has left gap which this study tried to fulfill by investigating the intervening variables. Purposive sampling was used to select four and two wards from Sabongari and Gagi wards. The choice of the selection was based on the preponderance of smallholder farmers in these locations. Two (2) villages were randomly selected from each ward. A random selection of twenty (20) farmers from each village gave a total of 120 respondents for the study. Data were elicited through a structured questionnaire. Data were analyzed using descriptive statistics and multiple regression technique. On the whole, age, farm income, non-farm income, interest rate and the distance were significant in determining the amount of saving by smallholder farmers in the study area. Thus, these factors have to be considered in designing strategies aimed at improving the savings of smallholder farmers.
\end{abstract}

Key words: savings; smallholder farmers; determinant
IZVLEČEK

\section{DETERMINANTE VARČEVANJA MED MALIMI KMETI V OKROŽJU SOKOTO SOUTH, SOKOTO STATE, NIGERIA}

Majhni prihranki v gospodarstvu lahko vodijo v neučinkovito črpanje sredstev za domača vlaganja. To bi lahko bil vzrok, da je Nigerija tako močno odvisna od zunanjega zadolževanja pri razvojnih in investicijskih projektih. $\mathrm{V}$ dostopni literaturi je na voljo zelo malo ali skoraj nič podatkov o kulturi varčevanja med kmeti na tem območju. Pomankanje teh pomembnih informacij je bila vrzel, ki jo skuša ta raziskava zapolniti s preučevanjem vplivnih spremenljivk. Izbrano je bilo selektivno vzorčenje za izbor štirih vasi in dveh območjih v provincah Sabongari in Gagi. Odločitev za izbor je temeljila na večinskem stanju malih kmetov na območjih. Na vsakem izmed območij sta bili naključno izbrani po dve vasi. Naključen izbor 20 kmetov iz vsake vasi je dal celokupno 120 respondentov $\mathrm{V}$ raziskavi. Podatki so bili pridobljeni $\mathrm{z}$ vprašalnikom in analizirani $\mathrm{z}$ opisno statistiko in multiplo regresijo. V celoti so starost, prihodek kmetije, prihodek iz nekmetijske dejavnosti, obrestna mera in razdalja do banke značilno določali velikost prihrankov malih kmetov na tem območju. Te dejavnike bi torej morali upoštevati pri oblikovanju strategij za povečanje prihrankov malih kmetov.

Ključne besede: prihranki; mali kmeti; determinante

\footnotetext{
1 Department of Agricultural Economics, Usmanu Danfodiyo University, P.M.B. 2346, Sokoto, Nigeria; "Corresponding author: e-mail: oyeyodeobalola@yahoo.com

2 Department of Agricultural Economics and Farm Management, University of Ilorin, P.M.B. 1515, Ilorin, Kwara State, Nigeria
} 


\section{INTRODUCTION}

In most developing countries, sustained growth in agriculture is often the keystone of overall socioeconomic growth and development (Dethier \& Effenberger, 2011). These agro-based economies have rural farmers as stakeholders in the path to agricultural development. In Nigeria, for instance, smallholder farmers account for about $90 \%$ of food production (Adams \& Vogel, 1990; CBN, 2004). The importance of agriculture in developing country, especially rural households, cannot be overemphasized - provides employment for 60 percent of the labor force: accounting for 25 percent of GDP and provides livelihood for 86 percent of rural households (Dethier \& Effenberger, 2011).

Due to the dominance of agricultural activities by rural farmers, improving rural food productivity and production is central to agricultural growth and development. However, smallholder farmers are confronted by peculiar circumstances and government policies and programmes which have limited their capacities for increased production. In many African countries, including Nigeria, lack of access to credit or its inadequacies is most frequently mentioned as a leading constraint to increased agricultural production. Generally, lack of access to credit by rural farmers is attributed to the fact that not only that most of the rural farmers rarely attain formal education, but also lack collateral, which virtually locks them out of the conventional banking system (Awotide et al., 2015). Worse still, credit obtained from informal financial institutions is not always enough for a meaningful increase in their agricultural production (Ike, 2009).

In view of the credit situation in rural sector, and the peculiar constraints surrounding credit availability to rural farmers, a sustainable way for capital formation for investment is via savings mobilization from rural farmers themselves to increase the amount of loanable funds in rural banks as well as to increase the extent to which they accumulate capital for farming (Vonderlack \& Schreiner, 2001; CBN, 2004). Savings is a common word used by individuals on daily basis. It is a means of accumulating assets that perform specific function for the saver (Ike \& Idoge, 2006). It is also the setting aside of some items for future use or what will be considered as deferred expenditure (Amu \& Amu, 2012). Savings plays a foundational role in economic development as it is a key to capital formation which is necessary for investment. There is proportional relationship between savings and investment as the size distribution of savings reveals a potential for further investment. If investment remains localized in accordance to size of savings generated in a specific area, there are likelihoods for reinvestment in areas wherein higher savings is recorded compared to those of meager savings (Odoemenem et al., 2013). Economic theory posits that high level of savings is translated to higher investment, with financial institutions playing the intermediation role of mobilizing and allocating financial resources from savers to investors. Thus, at the national level, savings are crucially important because they allow for investment which in turn creates jobs and enhances production. This leads to an increase in income, which permits additional savings and investments.

Most smallholder farmers utilize their savings for both agricultural and non-agricultural purposes (Odoemenem et al., 2013). Agricultural investments are in the purchase of agrochemicals - fertilizers and pesticides, hired labour, machineries and acquisition of land for farming. Investment in non-agricultural activities are mainly centered on education, trade expansion and other cultural obligations.

As stated earlier, inadequate savings, income and access to capital for investment is one of the basic challenges confronting agricultural development in Nigeria. Despite this challenge, there have been limited attempts to address the saving cultures in rural Nigeria (Odoemenem et al., 2013). Although studies have been conducted in Nigeria with the aim of determining savings and capital formation in the southern Nigeria, but due to the cultural difference between the rural dwellers in north of Niger River, it is necessary to understand the saving culture in Northern Nigeria. In the light of the foregoing, this study seeks to (i) describe socioeconomic characteristics of smallholder farmers in the study area; (ii) determine factors influencing savings among smallholder farmers in the study area; and (iii) identify the major reasons why smallholder farmers save in the study area. 


\section{MATERIALS AND METHODS}

\subsection{Study area}

Sokoto south local government area is located between latitudes $12^{\circ} 20^{\prime} \mathrm{N}$ and $13^{\circ} 58^{\prime} \mathrm{N}$ and longitudes $4^{0} 8^{\prime} \mathrm{E}$ and $6{ }^{\circ} 54^{\prime} \mathrm{E}$. It is bounded by Kware local government to the east, Wamakko local government in the west, Sokoto north local government in the north and DangeShuni local government in the south. The average rainfall is about $750 \mathrm{~mm}$, the mean temperature is 34.9 ${ }^{0} \mathrm{C}$. It has an area of $41 \mathrm{~km}^{2}$ and a population of 194,914 amongst which there are 102,270 males and 92, 644 females (NPC, 2006). Sokoto south local government is blessed with vast arable land and vegetation across its domain used for agricultural cultivation. The land is generally fertile for agricultural activities. Crops cultivated in the area include maize, guinea corn, millet, cassava, and potatoes in large quantities. There is also availability of large amount of livestock in the area. The livestock include cattle, sheep, goats, and poultry. Vast proportions of the people in the local government area are traders and are also involved in farming and other economic activities. Apart from the arable crops, economic activities like dyeing of cloths and tanning are also practiced.

\subsection{Sampling procedure}

Purposive sampling was used to select four (4) and two (2) wards from Sabongari and Gagi wards respectively based on the preponderance of small holder farmers in these locations. This gave a total of 6 wards. From each of the wards, two villages each were randomly selected. From each village, the lists of respondents were compiled. Random sampling technique was used to select 20 farmers from each village. This gave a total of 120 respondents.

\subsection{Data Collection}

The study used primary data for its analysis. Data were elicited in 2013 by the use of pre-tested and structured questionnaire administered in an interview schedule to the smallholder farmers. The data elicited include the socioeconomic characteristics of the farmers: age, sex, income (farm and off-farm), monthly savings and distance from financial institutions, among other information.

\subsection{Analytical technique}

To achieve the objectives of the study, set of statistical tools were employed in analyzing the data obtained. Descriptive statistical tools such as percentages and frequency were used to analyze the socioeconomic characteristics of the farmers and to identify the reasons for savings. Multiple regression technique was employed in the analysis of factors influencing savings by using the socioeconomic variables as proxies. The regression model was implicitly specified as:

$Y=F\left(X_{1}, X_{2}, X_{3}, X_{4}, X_{5}, X_{6}+X_{7}+X_{8}+X_{9}+X_{10}+e\right)(1)$

Where $\mathrm{Y}=$ volume of savings accumulated in a year $\mathrm{X}_{1}=$ Age (years), $\mathrm{X}_{2}=$ Farm size (hectares), $\mathrm{X}_{3}=$ Household size (Number of persons), $X_{4}=$ Farm income $(\mathrm{N}), \mathrm{X}_{5}=$ Non-farm income $(\mathrm{N}), \mathrm{X}_{6}=$ Experience from saving programme (Years),

$\mathrm{X}_{7}=$ Interest rate $(\%) \mathrm{X}_{8}=$ Household level of education (Years), $\mathrm{X}_{9}=$ Membership of organized group (Dummy) $\mathrm{X}_{10}=$ Distance to the nearest formal financial institution $(\mathrm{Km}), \mathrm{e}=$ Error term

The model was explicitly specified as:

$\mathrm{Y}=\beta_{0}+\beta_{1} \mathrm{X}_{1}+\beta_{2} \mathrm{X}_{2}+\beta_{3} \mathrm{X}_{3}+\beta_{4} \mathrm{X}_{4}+\beta_{5} \mathrm{X}_{5}+\beta_{6} \mathrm{X}_{6}+\beta_{7} \mathrm{X}_{7}$

$+\beta_{8} \mathrm{X}_{8}+\beta_{9} \mathrm{X}_{9}+\beta_{10} \mathrm{X}_{10+} \mathrm{e}$

Where: $\beta_{0}=$ Constant term; $\beta_{1}-\beta_{10}=$ Regression Coefficients. Other variables are as previously defined. 


\section{RESULTS AND DISCUSSION}
3.1 Socioeconomic characteristics of smallholder The socioeconomic characteristics of the farmers were farmers in the study area elicited and thus presented in Table 1.

Table 1: Summary of the descriptive statistics of the smallholder farmers

\begin{tabular}{|c|c|c|c|}
\hline Variables & Frequency & Percentage & Mean \\
\hline \multicolumn{4}{|l|}{ Age (years) } \\
\hline $20-35$ & 22 & 18.3 & \multirow{4}{*}{43.0} \\
\hline $36-41$ & 38 & 31.7 & \\
\hline $42-57$ & 43 & 35.8 & \\
\hline$>57$ & 17 & 14.2 & \\
\hline \multicolumn{4}{|l|}{ Household size (numbers) } \\
\hline$<3$ & 5 & 4.2 & \multirow{4}{*}{6.6} \\
\hline $3-6$ & 54 & 45.0 & \\
\hline $7-10$ & 46 & 38.3 & \\
\hline$>10$ & 15 & 12.5 & \\
\hline \multicolumn{4}{|l|}{ Famers education (level) } \\
\hline Primary education & 19 & 15.8 & \\
\hline Secondary education & 28 & 23.3 & \\
\hline Tertiary education & 35 & 29.2 & \\
\hline Islamic education & 38 & 31.6 & \\
\hline \multicolumn{4}{|l|}{ Farm size (hectares) } \\
\hline$<1$ & 45 & 37.5 & \multirow{4}{*}{2.7} \\
\hline $1-3$ & 37 & 30.8 & \\
\hline $4-6$ & 26 & 21.7 & \\
\hline$>6$ & 12 & 10.0 & \\
\hline \multicolumn{4}{|c|}{ Household income (Naira/annum) } \\
\hline$<20,000$ & 4 & 3.3 & \multirow{4}{*}{$71,758.33$} \\
\hline $20,000-50,000$ & 10 & 8.3 & \\
\hline $51,000-81,000$ & 27 & 22.5 & \\
\hline$>81,000$ & 79 & 65.8 & \\
\hline \multicolumn{4}{|l|}{ Mode of savings } \\
\hline Formal financial institution & 70 & 58.3 & \\
\hline Informal financial institution & 50 & 41.7 & \\
\hline \multicolumn{4}{|l|}{ Monthly savings(Naira) } \\
\hline $1-1000$ & 46 & 38.3 & \multirow{3}{*}{1217.07} \\
\hline $1001-2000$ & 50 & 41.7 & \\
\hline$>2000$ & 24 & 20.0 & \\
\hline \multicolumn{4}{|c|}{ Distance to financial institution $(\mathrm{km})$} \\
\hline$<1$ & 15 & 12.5 & \multirow{4}{*}{5.8} \\
\hline $1-5$ & 41 & 34.2 & \\
\hline $6-10$ & 43 & 35.8 & \\
\hline$>10$ & 21 & 17.5 & \\
\hline
\end{tabular}

Source: Field Survey, 2013

The mean age of the smallholder farmers was observed to be 43 years. The implication is that the smallholder farmers are middle aged and still agriculturally active. This however could have effect on agricultural production with the mean reflecting the age group that can withstand the rigours, and stress involved in agricultural production (Onyenucheya \& Ukoha, 2007). The mean household composition of the farmers was 7 persons with the majority $(52.5 \%)$ of them with secondary and tertiary level of education. As anticipated, higher education tends to enhance the ease of adopting innovation and hence increased farm income (Ezeh, 2007). On the distribution of farm size in hectares, it was observed that the average farm size was 2.7 hectares. Farmers with less than 1 ha constituted about $37.5 \%$ of the respondents and only $30.8 \%$ had 1 3 ha, an indication that the farmers are indeed operating on a small scale with a mean annual household income 
of $\mathrm{N} 71,758.33$. It can be seen that the average monthly saving ( $\mathrm{N} 1217.07)$ is $20.4 \%$ of the average monthly income (N5979) of the farmers. The distance of the farmers to financial institution at average, was about 5.8 $\mathrm{km}$.

\subsection{Factors influencing saving among farmers in the study area}

Multiple regression estimates on the determinant of saving in the study is presented in Table 2.

Table 2: Regression estimates for the determinants of savings among smallholder farmers

\begin{tabular}{lll}
\hline Variable & Coefficients & $\mathrm{t}$ values \\
\hline Constant & $7.124^{* * *}$ & 11.024 \\
Age (Years) & $0.039^{* * *}$ & 3.845 \\
Farm Size (Hectares) & 0.027 & 0.904 \\
Family Size (No) & 0.031 & 1.042 \\
Farm Income (N) & $0.165^{* * *}$ & 2.703 \\
Non-farm income (N) & $0.512^{* *}$ & 2.058 \\
Experience from saving programme (Years) & 0.016 & 0.531 \\
Interest rate (\%) & $0.120^{* * *}$ & 2.656 \\
Household level of Education (Years) & $0.182^{*}$ & 1.855 \\
Membership of organized group (Dummy) & -0.261 & -1.15 \\
Distance & $-0.295^{* * *}$ & -2.66 \\
R square value & 0.643 & \\
Adjusted R square value & 0.414 & \\
F Statistics & $25.97^{* * *}$ & \\
\hline Source: Fies Survey & &
\end{tabular}

Source: Field Survey, 2013.

Note: $* * *$ significant at $1 \%, * *$ Significant at $5 \%, *$ Significant at $10 \%$

The estimated determinant function is shown in Table 2. It shows a $\mathrm{R}^{2}$ value of 0.643 . This is an indication that $64.3 \%$ variability of farmers' saving is attributed to the specified explanatory variables in the model. This shows that the specified explanatory variables were important determinants of saving among respondents. The $\mathrm{F}$ statistics confirms the suitability of the overall regression equation and it is however significant at $1 \%$ probability level.

The coefficient of age is positive and in conformity with apriori expectation of the amount of savings accumulated. This positive relationship implies that older farmers save more. This is in agreement with the work of Attanasio \& Szekely (2000) who found that savings capacity is enhanced as age increases. Old people tend to be more frugal and thrifty. This may be due to the facts that middle aged people are required to save more, owing to the financial obligations for their immediate families.

The farm income is expected to bear a positive relationship with the volume of savings. The result of this study shows that volume of savings was sensitive to farm income of the farmers as this was found to be significant at $1 \%$. This implies that the higher the farm income, the more likely a farmer would save or accumulate capital to meet investment demands. This corroborates the findings of Adeyemo \& Bamire (2005).

Non- farm income turnout is one of the major determinants of savings in the area. Non-farm income is statistically significant at $5 \%$. This implies that the earning from non-farm activities is likely to influence their level of saving. If they are intensively involved in these non-farm activities like petty trading, transportation business, non-agricultural processing, sewing etc., they are likely to save more capital than those who are not involved.

Interest on amount saved has a positive and significant coefficient. This corroborates theoretical expectation. This implies that smallholder farmers will continue to save even with a marginal interest. This may be affirmed to the distribution of society's surplus according to members' patronage (in terms of savings, purchase and loan) at the end of the accounting year and could serve as a way in motivating members to keep saving at higher rate.

The relationship between the level of savings and distance to financial institutions is negative. Its coefficient is statistically significant. This implies that farmers' proximity to financial institutions is one of the major determinants of level of saving because the nearer farmers are to financial institutions, the more the likelihood of saving some part of their income.

\subsection{Major reasons why smallholder farmers save in the study area}

The various reasons for savings as attested to by the farmers through multiple responses to items are presented in Table 3. 
Tohib Oyeyode OBALOLA et al.

Table 3: Reasons for Saving

\begin{tabular}{lll}
\hline Reasons & Frequency* & Percentage \\
\hline Precautionary motive & 63 & 52.5 \\
Capital formation & 115 & 95.8 \\
Sense of independence & 31 & 25.9 \\
\hline
\end{tabular}

Source: Field Survey, 2013, * Multiple response

Capital accumulation (capital formation) was observed by $95.8 \%$ as the reason why they save. This will in turn help increase their level of agricultural production while over $52.50 \%$ of the respondents save as against precautionary motive aimed at tackling unforeseen circumstance that might evolve during the production period and as well ensuring the proper education of their children. To marry more wives so as to add to the family labour input might be a good reason for the response on sense of independence by the farmers.

\section{CONCLUSION}

The study examined the determinants of savings among smallholder farmers in Sokoto south local government area of Sokoto State, Nigeria. Ten parameters were fitted into the regression model and only five were found to be significant determinant of saving. It shows that these socioeconomic variables have impact on the farmer's level of savings. It can also be concluded that these farmers save in order to accumulate capital which might enhance their production. As such farm level, policies which remove agricultural production constraints will increase the farmer's income and promote accumulation of financial capital in form of savings among farmers. Also the determinants of savings as observed should be considered in designing strategies aimed at improving the savings of smallholder farmers.
Given the significance of the income (both farm and non-farm) to the improvement of savings among farmers, appropriate financial instruments such as medium and long term loans should be provided by financial and other credit institutions to farmers in order to boost their income level. Only then, the savings being accumulated in the rural economy can be transformed into productive investment that will enhance or uplift their present standard of living.

Finally, to improve savings among smallholder farmers in Nigeria, technologies - mobile banking - that bring financial institutions close to smallholder farmers should be encouraged among the farmers via their relevant farm associations. This will in turn improve their saving cultures as this strongly relates to distance from financial institution.

\section{REFERENCES}

Adams, D. \& Vogel, R. (1990). Rural financial market in low - income countries agricultural development in the third world. Baltimore: John Hopkins University Press.

Adeyemo, R. A., \& Bamire, A. S. (2005). Saving and Investment Patterns of Cooperatives Farmers in Southwestern Nigeria. Journal of Social Sciences, $11 \quad$ (3), $\quad 183 \quad$ - 192. doi:10.1080/09718923.2005.11892512

Amu, M. E. K., \& Amu, E. K. (2012). Saving Behaviour in Ghana: A Study of Rural Households in the Ho Municipality of the Volta Region. Online Journal of Social Sciences Research, 1 (2), 54-61.

Attanasio, O. P., \& Szekely, M. (2000). Household Saving in Developing Countries - Inequality,
Demographics and all that: How Different are Latin America and South East Asia? Inter American Development Bank. Research Department. Working Paper Series. No 427, 1 - 63.

Awotide, B. A., Abdoulaye, T., Alene, A., \& Manyong, V. M. (2015). Impact of Access to Credit on Agricultural Productivity: Evidence from Smallholder Cassava Farmers in Nigeria. A Contributed paper Prepared for Oral Presentation at the International Conference of Agricultural Economists (ICAE) Milan, Italy August 9-14, 2015.

CBN (2004). Central bank of Nigeria annual report and statement of accounts. CBN, Abuja, Nigeria

Dethier, J., \& Effenberger, A. (2011). Agriculture and development: a brief review of the literature. Policy 
Determinants of Savings among Smallholder Farmers in Sokoto South Local Government Area, Sokoto State, Nigeria

Research working paper; no. WPS 5553. Washington, DC: World Bank. http://documents.worldbank.org/curated/en/389411 468330915034/Agriculture-and-development-abrief-review-of-the-literature

Ezeh, C. I. (2007). Poverty Profiles and Determinants of Expenditures of Rural Women Households in Abia State, Nigeria. The Nigerian Journal of Development Studies, 6 (1), 187 - 204.

Ike, P. C. \& Idoge, D. E. (2006). Determinants of financial savings among rural households in delta state, Nigeria. Journal of Applied Chemistry and Agricultural Research, 9, 95-103.

Ike, P. C. (2009). Credit availability, utilization and repayment among smallholder women crop farmers in Enugu state, Nigeria. Faman Journal, 10 (1), 18.

NPC (2006). National Population Commission Report. www.population.gov.ng/index.php/cc.

Onyenucheya, F., \& Ukoha, O. O. (2007). Loan Repayment and Credit Worthiness of Farmers under the Nigerian Agricultural Co-operative and Rural Development Bank (NACRDB). Agricultural Journal, 2 (2), 265-270.

Vonderlack, R. \& Schreiner, M. (2001). Microfinance and savings: Lessons and proposals. Working paper 01-5, Centre for social development, Washington University, St. Louis. 